\title{
Discourses on gender in early childhood education and care (ECEC) setting: Equally discriminated against
}

\section{Dragana Pavlović Breneselović, Živka Krnjaja}

Abstract: The paper addresses gender issues in the practice of ECEC through research with children. The research examines children's perspectives of kindergarten practice, acknowledging the importance of the child's perspective in critical investigations of this nature. In total, fifty children from thirty kindergartens across Serbia participated in the research involving the Mosaic method. Qualitative analysis through three iterative phases helped identify emergent themes. The themes were not imposed by the researchers but emerged from the children's narratives generated around photographs and drawings they had produced, map-making and kindergarten tours. One of the emergent themes captured in the children's narratives related to gender issues and helped us map the three pathways of data synthesis: gender segregation and stereotyping, gender discrimination, and close friendships. The examples of children narratives indicate that no particular gender discourse informed the teachers' practices nor did they critically re-examine gender issues. This consequently led to the perpetuation of gender segregation and stereotyping, as well as gender discrimination against boys and girls. Thus, we argue that ECEC practices should be further re-examined to with a view to improving gender equity.

Key words: gender discourses, ECEC, feminist pedagogy, research with children.

\section{Introduction}

Early childhood is an important period in forming gender identity. A child's gender identity is shaped and re-shaped through interaction with peers, adults and the wider socio-cultural context (Browne, 2004; Mac 
Naughton, 2003). ECEC practice is an integral part of this context and plays an important role.

The complex issues of gender equity and gender typing have not been sufficiently addressed in Serbian ECEC practice. As a postsocialist country, Serbia nominally adheres to the principle of gender equality from an equal opportunities perspective. At the same time, the process of re-building state sovereignty following the disintegration of Yugoslavia and subsequent national conflicts has prompted a tendency to strengthen national identity through a return to a national cultural tradition that favours traditional gender roles and identities (Jarić, 2006). In addition, gender issues have not been explicitly addressed within the curricula in initial preschool teacher education. Rather, the issue of gender is primarily discussed as part of traditional developmental psychology theories of socialization (Krnjaja \& Pavlović Breneselović, 2013). Apart from a general discussion of equality, the National ECEC Curriculum Framework does not focus explicitly on gender equity issues (Ibid).

Our interest in gender stems from research with children conducted within the Serbian system of ECEC. Research with children is increasingly part of early childhood education today as a means of acknowledging the importance of the child's perspective, participation and voice (Dalli \& Stephenson, 2010; Clark, Kjørholt \& Moss, 2005; Cunningham et. al., 2004; Einarsdottir, 2005; Harcourt, 2008; Mac Naughton, Smith \& Lawrence, 2008; Mahony \& Hayes, 2006). These approaches are largely based on sociocultural theories of learning and development, the sociology of childhood and poststructuralist theory (Anning, Cullen \& Fleer, 2004; Dahlberg, Moss \& Pence, 2007; James \& Prout, 2005; Mac Naughton, 2003, 2005; Qvortrup, 2005; Rogoff, 2003). What these all share in common is the understanding that children are active and competent learners who can achieve their potential; that children's agency and participation are of the utmost importance; and that it is through child-adult collaboration and by deconstructing existing power relations that participation in the community of practice becomes a process transforming all actors.

Research with children is based on the following epistemological and methodological premises: 1) Researchers acknowledge the existence of multiple perspectives and experiences, as opposed to the 'objectivity' and generalization usually assumed by those conducting research about children using a positivist methodological paradigm (Christensen \& James, 2008); 2) The role of the child in the research process has changed from that of 
being the 'object' of the research to that of adopting the role of an active coresearcher. Children actively participate in the development of the research process by introducing new research questions and topics or by shedding new light on existing ones. Children also choose the techniques and methods used to narrate the themes, participate in the analysis and interpretation of the research data, and create research reports (Kellett, 2005); 3) The act of performing research is a process in which relationships, mutual understandings and meanings develop between children and adults, which can be contrasted with research that is carried out on children where the child is only used as a resource for data collection (Clark \& Moss, 2001); 4). Unlike the positivist depiction of data collection as a neutral fact-gathering process that takes place independently from the researcher, research with children is an active and inter-subjective process (Alldred \& Burman, 2005; Peters \& Kelly, 2011).

According to Mac Naughton et al. (2008), by recognizing the child as an active participant in the research process, we accept three key ideas: "young children can construct valid meanings about the world and their place in it; young children know the world in alternative (not 'inferior') ways to adults; young children's perspectives and insights can help adults to understand their experiences better" (Mac Naughton et al., 2008, p.15).

Sommer, Pramlin Samuelsson and Hundeide (2010) emphasize the conceptual difference between 'children's perspectives' and a 'child perspective'. Children's perspectives refer to the children's point of view, their experiences and understanding of the world they live in. The child is the subject and has his/her own perceptions, experiences, and understandings. Adults can attempt to understand the child's perspective by listening to what he/ she is saying and observing his/her behavior (Ibid). Although any attempt to understand the child's perspective is always subject to the adult's interpretation - how adults make sense of what children tell them (Bronfrebrenner, cited in Pramling Samuelsson, 2004) - our understanding develops as we attempt to hear what the children are saying. According to Pascal and Bertram (cited in Peters \& Kelly, 2011), researching the child's perspective is a process that is "complex, challenging and multi-layered involving a profound paradigm shift in the values, actions and thinking of researchers and practitioners" (p.27).

By contrast, the concept of a 'child perspective' refers to our understanding of children's perceptions, experiences and actions in the world. Although focused on the child, the 'child perspective' is the adult's objectification of the 
child, as it is rooted in the way the adult sees the child. The way an adult sees the child is a reflection of the adult's attempt to understand the child's experiences and worldview and is an attempt to explain and systematize his/her own understanding of the child's perspective. Thus, "a child perspective is not an empirical fact emerging from the study of children's statements and actions alone but rather an analytical construct, related to one's theoretical considerations" (Gulløv\&Højlund, cited in Sommer et al., 2010, p. 21).

Starting from this distinction, our key research question was: What are children's perspectives of regular kindergarten practices and how do they perceive the activities, space, adults, relationships and themselves in this context? Analyzing children's narratives about the space, activities and relationships in kindergarten, we became aware of the continual presence of the theme of gender. Thus, the gender issue emerged through our research with the children, prompting further inquiry into the 'child perspective' (Sommer et al., 2010). In other words, we attempted to better understand kindergarten practice in the context of gendered relationships by interpreting and understanding the children's perspective from our theoretical standpoints.

Based on an overview of the literature, we identified three discourses on gender that would serve as a basis for further interpretation of the data: biological determination of gender; socially determined gender in the interplay of nature and nurture; and sociocultural determination of gender. Each of these discourses shapes kindergarten practice in different ways because, as Browne (2004) points out, "discourses produce or create 'reality' by providing conceptual frameworks for determining what can be said, written and possibly thought and for making sense of our experiences and the experiences of others" (Browne, 2004, p.7).

\section{Gender identity as biologically determined}

Gender identity is significantly influenced by biological factors and "gender is [a] natural, stable" binary category (Grewal \& Kaplan, 2006, p. 32). The existence of biologically determined gender differences has been supported by recent neuroscience research on differences between the male and female brain (Browne, 2004). The research findings show that differences in brain functioning in males and females from the moment of birth are due to the influence of hormones on brain development. As these differences appear very early, it is assumed that they have been caused by gender specific genes and hormones (Berger, cited in Wardle, 2007). The differences begin in the prenatal period when the gender hormones start to influence brain 
development and continue to do so during further development. Some authors argue that the gender differences in brain development are reflected in the slightly differing developmental timetables found in boys and girls (Landers, 2002; OECD, 2010). Measurements of cognitive and sensory development show that girls have a more advanced developmental timetable: vision, hearing, smell and tactile senses, as well as memory develop faster in baby girls than in baby boys. Baby girls also show a higher social sensibility, react more readily to the human voice, face and crying of another child. According to research in this area, on average girls exhibit faster development in fine motor skills and speech, while boys perform better on visually-spatial coordination and integration (Ibid). These findings indicate that the hormonal differences and the different trajectories of brain development between the genders could be reflected in children's choices of activity and play (Berk, as cited Wardle, 2007), especially when accompanied by the social determinants and mechanisms that reinforce such differences: for example, boys are physically more active, engage more in rough and tumble play, and are more inclined towards kinaesthetic learning and practical manipulation than are girls.

Kindergarten practice, when shaped by this discourse, will take these differences for granted and, if they are not properly re-examined and problematized, it will continue to maintain them. As Browne (2004) has pointed out:

Within essentialist discourses of gender, for example, stereotypical play preferences of girls and boys would be viewed as a natural expression of biological differences. Educators would feel that such behaviour is natural and therefore would be unlikely to intervene. Indeed, intervention is only likely to occur if children are seen to be to playing in an 'unnatural' manner (e.g. girls physically play-fighting or boys consistently playing with dolls). (p.7)

\section{Gender identity as socially shaped in interplay of nature and nurture}

The same research on brain development has also led to closer examination of the exclusiveness of the essentialist position, by acknowledging that development occurs through the interplay of nature and nurture (Shonkoff $\&$ Philips, 2000), and that biologically determined gender differences should be understood as general tendencies only (Browne, 2004). Most researchers agree that there are more similarities than differences between boys and girls as social groups; however, there is much variation within each gender group, and this variation is often larger than the differences among groups 
(Ibid). Neuroscientists agree that genes and hormones trigger differences in brain development in boys and girls but that individual experiences still play the most important role (National Scientific Council on the Developing Child, 2004; OECD, 2010). This research further emphasizes that the plasticity of the brain provides opportunities for compensation through experiences.

From this perspective, by projecting social and cultural expectations on accepted behaviours associated with a particular gender, family members, preschool teachers, peers and community role models have a prime influence on the development of gender identity (Bandura, Basow, Measor $\&$ Seakers, according to Blaise, 2005). The practice in this discourse is sensitive to gender segregation and gender stereotypes. The attempt could be made, not to discourage children from playing games of their own choosing, but to supplement and upgrade these games by providing different experiences to compensate for the biological determinants: for example, that would support verbal development in boys and visual spatial coordination in girls.

In the discourse of gender socialization the important issue for practice is the prevalent feminization of preschool education with almost exclusively female staff working in ECEC. For example, in the majority of EU member states, with the exception of the Nordic countries, male staff account for less than 3\% of those employed in ECEC (Moss, 2000) - ECEC can thus be referred to as a 'gender ghetto' (Rolfe, 2006). The predominance of female staff within ECEC reflects and further shapes perceptions of teachers' work and the 'family replacement' role of the kindergarten: educating small children is work that women are destined to do and are 'naturally' good at, unlike men (Browne, 2004; Cameron in Moss, 2000). It has been emphasized that the overall kindergarten culture reflects the dominant stereotypical feminized culture' (Walkerdine in Burman, 2005). Its routines, rituals and rules favour a culturally influenced image of girls. Researchers argue that female teachers more frequently organize and participate in activities preferred by girls, such as storytelling, drawing, dramatization, and role playing (Wardle, 2007); that female teachers find it more difficult than male colleagues to differentiate between rough and tumble play and aggression (Tavecchio in Peeters, 2007); and most female teachers consider the 'ideal child' to be a girl, while the characteristics associated with the 'male side' have often been perceived to be negative (Ibid). From that standpoint, it is crucial to establish a mixed gender structure within the profession, which will allow for greater 'gender visibility' and create the conditions under which gender stereotypes can be questioned and provide experiences of gender equity for children (Moss, 2000; Rolfe, 2006). 


\section{Gender identity as socioculturally constructed}

From the sociocultural perspective, development is a process shaped through culture in which what it means to be a boy or girl has been socially constructed and co-constructed (Blaise, 2005; Browne, 2004; Mac Naughton, 2000; Robinson \& Diaz, 2006). "The construction of gender is a systematic process that begins at birth and is continually shaped, moulded and reshaped throughout life" (Yelland \& Grieshaber, 1998, p.2). Children learn socially appropriate ways of giving gender related performances and maintain these discourses so as to achieve a recognizable and acceptable identity in that particular social framework (Davies, cited in Browne, 2004). Gender segregation is constructed and negotiated within the child's peer culture; it is not a universal phenomenon related to biological and cognitive factors (Aydt \& Corsaro, 2003; Browne, 2004; Mac Naughton, 2000).

From a postpsychological (Blaise, 2005) and feminist poststructuralist perspective, the notion that boys enjoy being physically active, running and engaging in rough and tumble play while girls prefer being quiet, 'sitting still and chatting between themselves' is considered to be a discourse that places expectations on boys and girls, in addition to establishing and maintaining differences between them (Hogan, 2013; Mac Naughton, 2002, 2003; Robinson \& Diaz, 2006). Gender is seen as being fluid and dynamic, constructed jointly and collectively through interaction involving the operation of power as particular world views become culturally dominant or hegemonic (Gramsci in Edley, 2001). Only through interactions within the processes of construction, co-construction and re-construction are multiple personal and social identities developed (Brooker \& Woodhead, 2008; Mac Naughton, 2000).

Thus, the key role of teachers working with small children is to question the dominant discourses, overcome the bi-polarized and limited views on gender promoted by the classical theory of socialisation and create conditions for different ways of being and acting (Blaise, 2005). "Rather than one gender identity, individuals, including teachers and children, perform a number of gendered ways of knowing and being that depend on the social context and the meanings prevailing within a set of social relationships" (Grieshaberas in Hogan, 2012, p.2). Addressing the issue of gender equity in ECEC is seen as integral to promoting social justice among children, families and practitioners (Robinson \& Diaz, 2006). That way, practitioners would become agents of social change as their practices, seeking the 'transformation of opportunities' for individuals and groups, would lead to 
the transformation of society itself by promoting equity and social justice (Mac Naughton, 2003, p.188). Educators would, as Browne has pointed out "among other things, take steps to help the children to explore their understandings of 'feminine' and 'masculine' as part of a process aimed at supporting them in comprehending who gains and who loses within their current gender framework and working towards helping them to develop less restrictive ways of being 'feminine' and 'masculine"' (Browne, 2006, p.7).

\section{Methodology}

The key purpose of our research was to identify the dominant discourses on gender identity that shape current kindergarten practices in Serbia using data collected in research on the child perspective of kindergarten practice.

In our consultations with the children, we used the Mosaic approach developed by Clark and Moss (Clark \& Moss, 2001; Clark, 2005). The Mosaic approach is a creative way of listening to and consulting small children on their opinions by integrating different research techniques to provide the basis for all-encompassing research on the children's perspective. These techniques could be standard techniques used in ethnographic research, such as participant observation and open and/or semistructured interviews; multisensory or participative techniques including children acting as videographers, photographers, and audio recorders; the creation of maps and tours; and children's expressive activities, such as drawing, role playing, and the dramatization of events (Clark, 2005; Davies \& Thurston, 2006; Einarsdottir et. al., 2009; O'Kane, 2008). Children record and photograph spaces and activities that they like or dislike providing us with evidence of the places, activities, people and relationships that are important to them (Clark \& Moss, 2001). In that context, a photo, audiorecord or drawing could serve as a starting point in a conversation with a child or group of children on a specific question, as a means by which children could express their own experiences without having to verbally articulate them, and as a method for children to collect data on their own and initiate topics of interest. The Mosaic method comes from hermeneutic phenomenology - it is iterative, multi-layered, and interpretative. It involves re-examining research topics on the basis of new emergent data by taking into account the 'whole picture'. Hermeneutic phenomenology entails integrating children's drawings, photographs and maps with children's narratives about them, which requires the researcher to form an interpretative understanding through a dialogical process in which questions and answers generate opportunities for them to understand the world, others and us from a new perspective (Gadamer, 2011). 
The consultation process with the children was operationalized by linking the main research themes with particular research techniques using seven steps (Figure 1).

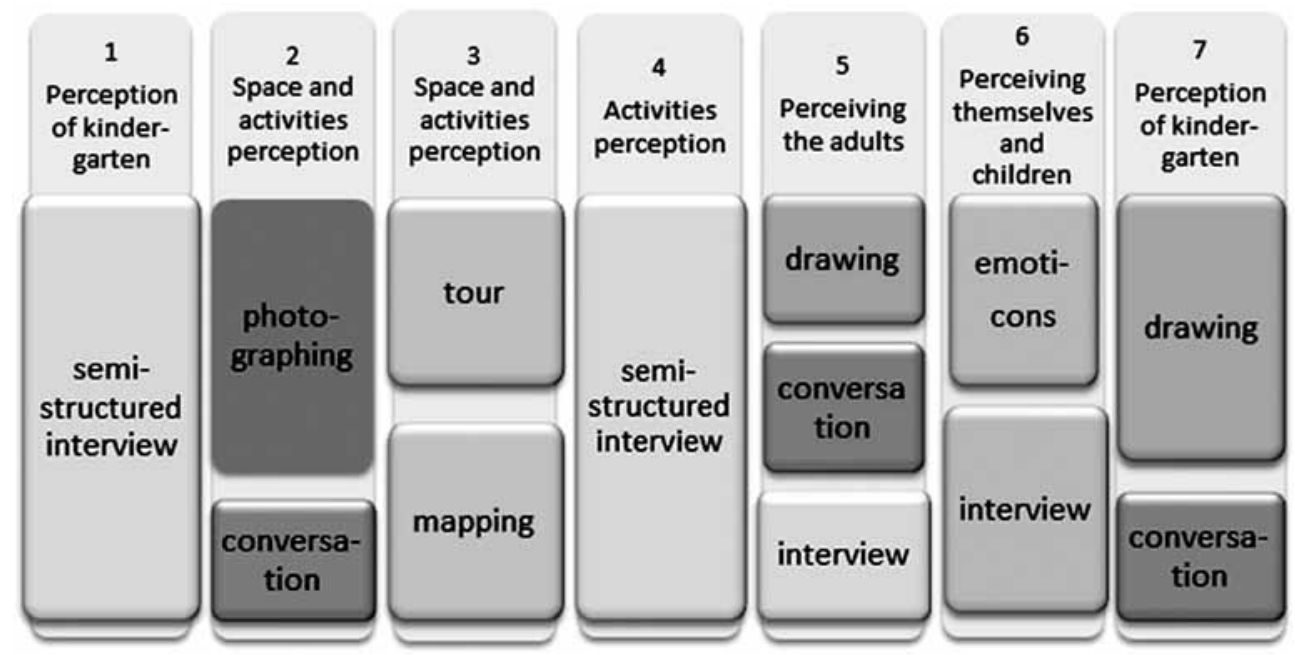

Figure 1. Research themes, steps and techniques

In our research, the main themes were children's narratives about kindergarten/ kindergarten space/activities within the kindergarten/ adults in the kindergarten, and narratives about the children themselves in relation to peers and adults. We used the following techniques: semistructured interviews; conversations around photographs taken by the children and the children's drawings; tours of the kindergarten with the children; maps produced by the children of the space and activities' and structuring conversations using emoticons.

Fifty children, 30 girls and 20 boys, aged 5 to 5.7 years from 30 state-run kindergartens across Serbia participated in the research. Prior to the research, the children had been informed about its purpose and methodology. The consultation with each child was conducted in a regular kindergarten setting, at different times over a three to five day period, depending on the child or kindergarten. The times of consultation were scheduled according to the children's preferences.

The data gathered using the different techniques through the consultations with the children were integrated to produce a unique protocol for each child, and coded according to gender and kindergarten location (in the summary of results, a unique code is assigned to each narrative example), lead- 
ing to the creation of a unique 'narrative sheet'. The qualitative data analysis was conducted in three iterative phases. In the first phase, referred to in the literature as the reduction phase (Berkowitz, 1997; Maxwell \& Miller, 2008), we completed the process of coding using a matrix of research themes, we then categorized the coded data, calculated the frequencies of the emergent categories and sub-categories, and conducted the data analysis. This step involved the process of inductive analysis, in which the themes, categories and patterns were induced from the data. It enables transparency and for new themes to be identified from the data and not specified in advance. In this phase the data was sorted to allow us to identify new themes that would serve as the conceptual frames used as exploratory structures in the second and third phases. It is interesting to note that gender was one of the themes identified in this way.

The second phase consists of 'multiple rounds' in which the data were revisited as additional questions, new connections and understandings emerged (Berkowitz, 1997). This phase is considered to be more reflective than the process of induction based 'objective' analysis, where the themes emerge in respect of what researchers want to know and how they interpret the data from their ontological and epistemological position and intuitive understanding (Sandelowski \& Barroso, 2007). This phase allowed us to identify, categorize, and map patterns within the data matrix using the meanings, associations and connotations of the narratives (Denzin \& Lincoln, 2011; Hatch, 2002; Parkerasas cited in Alldred \& Burman, 2005).

Finally, the third phase involves a process of reflective iteration when dealing with the data and linking them to new insights which progressively lead us towards a clearer focus and deeper understanding of the emergent patterns. It is not mechanic repetition but a reflective process in which new insights and meanings are developed (Berkowitz, 1997; Denzin \& Lincoln, 2011; Hatch, 2002). In our third phase the data synthesis could be compared, according to Sandelowski and Barroso (2007), with a kaleidoscope whose parts create different images whenever the kaleidoscope is rotated. In our research, the data gathered in the first and second phases were synthesized using the following categories: gender segregation and stereotyping; gender discrimination through typification; and close friendships and sympathies. 


\section{Results and Discussion}

Gender segregation and stereotyping

During preschooling gender stereotyping among children can be strong and could lead to rigid rules and prejudices. This usually reflects the gender stereotypes in that particular cultural context and immediate environment and is accompanied by a tendency for children to associate external features, such as clothes, toys or activities, with genuine gender determinants (Aydt \& Corsaro, 2003). Our data indicate that kindergarten culture frequently reinforces the prescribed societal gender typing instead of problematizing it and creating the conditions under which it could be further re-examined. The following examples illustrate the way in which children speak about boys' and girls' play centres and toys as well as the distinctions made between games for boys and games for girls:

Take a look around the room and show me where you don't like playing?

I don't want to play as a hairdresser and work in the kitchen and play with babies, I don't go in there. It's not for boys. Masha and Lena play with dolls, ask them. /SM17/

[Explanation of a photo of a disliked place]

This place where boys play is very boring and stupid.

Why do you find it boring? Because everything from boys is stupid and because they tell us that we are stupid. / BZ2O/

This is a place where the girls are all the time. Why do you dislike this place?

Because there are only girls there and everything there is for girls. /BM06/

Because only boys go there and they play only boys'games. / BZ20/

[Explanation of a photo of their favourite place]

What do you call the place you photographed, the place where you like playing the most?

Men's castle.

Who named it?

Well, us. The boys.

How come you call it that? 
Because only boys play there.

So, girls are not allowed to enter it?

No, they have to say the password.

Do the girls know the password?

No.

There is no way they can enter the castle?

No. Because nobody will tell them the password.

What do you do in the castle?

We play. It is like a real castle, we have guards, kings. We have a chef with a white hat. And a court jester. And servants.

And who are the servants?

That would be the girls, but we don't let them in.

So, there's a place where girls can't go. Is there a place where you can't go?

I am a boy. I can go anywhere. /BM14/

Although making distinctions and underlining differences could be a way of acquiring social knowledge on 'gender-appropriate' traits, children need to simultaneously learn activities to contest gender stereotypes. Children receive diverse messages linked to gender which are inherent to and influenced by social and cultural context. Gender segregation is also an issue constructed and negotiated in children's peer culture (Aydt \& Corsaro, 2003; Browne, 2004; Mac Naughton, 2000). Children's narratives indicate a desire to negotiate and reconstruct stereotypes; however, they do not show any teacher support for such a desire.

I don't like going and playing there because it's for girls and it's boring. I never play there except sometimes when we agree to be brothers and sisters./BMO2/

I like to play chase and run, Smurfs, tag and that's it.

How do you play Smurfs?

Well, we play by episodes. Yesterday we played the $3^{\text {rd }}$ episode where Gargamel transforms into a baby. And then we split into groups.

Oh, yes. How do you split?

Well, somebody is Gargamel and he has helpers, the others are Smurfs and one girl is Smurfette.

And who plays this game?

Me, Jakov and Dule are Smurfs, Nadja is always Smurfette, Gargamel is always Aleksa and his helpers are Nemanja, Nikola and Marko.

And why is Nadja the only girl who plays with you?

Well, because there is only one Smurfette and Nadja likes running. 
Sometimes other girls wants to play and we let them be Village girls... /BM16/

[Explanation of a drawing of their favourite place]

First of all we were sitting and then we went to make poison for the boys. We were looking for the ingredients that we need.

Who did you make the poison for the boys with?

With my best friends Una, Maja and Jovana.

We can see four people in the picture. Who is the fourth person?

That was a boy who was hiding to see what we were doing.

Did he discover what you were doing?

No, because we chased him away.

Why did you make the poison for the boys?

The boys are very bad and we are good.

How do you know they are bad? What did they do that makes you think they're bad?

The boys made traps for us. They dig a hole and cover it with leaves. They made a hole so that we girls would fall into it, get dirty and get stuck.

Did you tell anybody about these traps?

I didn't tell anybody except my friends.

Why didn't you tell the teacher?

Because we girls decided to solve the problem ourselves.

And did you succeed?

Well, we are trying, doing our best. And the boys are not so bad. They only do these kinds of things sometimes. /BZ22/

Children make decisions about gender related messages shaped by the context in which they act and develop their identities. While making these decisions, children should not be left entirely on their own and to the prescribed gender stereotyping encouraged by society and mass culture. Rather, children need teachers to support and encourage them in that process.

\section{Discrimination against boys based on gender typing}

The group of 50 teachers who participated in the research contained only two men. The data suggest that teachers frequently 'favour girls' over boys because girls behave in a way that corresponds to the prevailing 'feminized' kindergarten culture. 
Do you think that you are important in the kindergarten here?

I am. You should know that because when there are cute children like me, then they like to take me everywhere and show me off, and it is not difficult for me because I like drawing and talking./SZ18/

How do you know you are important in the kindergarten?

Because they're happy. They like it when I come in. Because I'm pretty and wear nice clothes./BZ19/

Girls can also identify more easily with the 'woman's role' of a female teacher:

The teacher tells stories like my grandma, so I like listening to her and she's very pretty so I like seeing what she's wearing. /SZ18/

[Explanation of a drawing of a good teacher]

Here we make a circle so we can play at skipping. I draw me and Vanja and the teachers with us.

I like the teachers because they're kind to us.

Why do you think they're kind to you?

They teach us songs, when we want to play together they play with us, play music for us when we want them to.

Good, what else would you add to this drawing, do you want to add anything?

Yes, I want to add a heart, I like drawing hearts.

Why do you like drawing hearts?

Because my teacher J draws hearts. /SZ16/

Teachers tend to form closer relationships with girls. In our research, only the girls mentioned being welcomed by the teachers with a kiss, a hug, and physical contact upon arrival at the kindergarten. Moreover, it seems that teachers frequently rely on the girls when they ask for help. Children perceived helping teachers to be an indicator of their importance and status in the kindergarten. Responding to the question about how they knew they were important in the kindergarten, the girls talked about helping the teachers:

Yes. They need us to make the room nice, to draw the piano and other instruments so they can pin them on the board like those butterflies. Because we learn things. Because I know some nice songs I can play on the piano. When we help them to make ladybirds and butterflies. /SZ17/ 
Well, sometimes I am needed when the teacher needs me. For example, you are the teacher. No, I'm the teacher and you're the child and now I want you to sit next to me and we'll do some jobs. /SZO9/

On the other hand, when we asked the boys to talk about their favourite activities, the data suggest a preference for physical loud activities and for a larger space in which to do kinaesthetic activities and play:

[Explanation of a photo of their favourite place]

I can play Ninjas warriors, Mane brings the Black Blade and we all play together. We fight, hit each other but it's all 'pretend'. / MBO3/

Yes, that's where I like! (Points to the stage in the drama centre)

And why do you like the stage?

All my toys are there and I like rolling on the floor, there's enough space! And what do you most like to play at on the stage?

I most like to play alone because nobody bothers me.

Yes, I like it here on the carpet too, for rolling on the floor.

Here, you see, here are some toys, cars and blocks. I like it here. /MB13/

And why do you like playing there in the middle of the room?

Well, it's in the picture (showing the photo he took).

I see, but I would like it if you could explain to me why you like playing there?

We all like running and like running there, it's always fun. /BM16/

Can you show me on this map where you spend most of your time? What's that?

A city.

Why do you want to be there?

Because it's nice, there are toys you can play with on the carpet, not at the table. /BM10/

The preceding examples indicate that the boys' preferences could frequently contradict the basic teacher request that children 'stay still and be quiet':

What does your teacher like?

When we are nice, when we talk quietly, when we play, when we don't jump...Yes! And when we don't run around the room and when we sleep. When we're all good and obedient. /SMO4/ 
When we're all quiet and we don't make a noise. /SM12/

[Explanation of a drawing of a good teacher]

You see, this good teacher is writing letters, you see she is drawing them. Ann [a teacher] is also here and she is helping Anica [another teacher]. They sit and they like to whisper things, and they have a lot of paper on the table because they want to write. This is paper and this and that [shows me while she is drawing]. These are 'quiet' children, there aren't many of them, there is no Filip and you know him. This is me. Taca is beside me. Our table is huge, see the table and chairs. There aren't many children, only we came as the others were sick. /BZ22/

Thus, it is not surprising that boys tend to mention punishment more frequently and receive messages that they are 'bad' and 'naughty':

I have to be good, but really good. I shouldn't listen to the bad boys, or touch the teacher's stuff and I have to play nicely, kindly and wonderfully. /SZ17/

What does being good mean?

That you are nice and that you don't yell and scream.

And what else?

And not go wild.

And how do you go 'wild'?

I'll show you now.

He starts jumping, then rolls on the floor and shrieks. /BM16/

How a child understands and regulates his/her emotions and needs is closely related to the way teachers and peers perceive his/her social competences and how well the child is accepted by the peer group and in the ECEC setting (National Scientific Council on the Developing Child, 2004). Frequent reprimands and punishments, and labels such as 'bad', 'naughty', 'hyperactive', etc., could lead to boys being pushed into a vicious circle in which they end up 'playing an assigned role' and reinforcing the image created by others, rather than them being encouraged to exhibit self-control and change their behaviour.

Do you try to be nice?

We all try. All children are good. If somebody says "you are bad", you respect that. /BZ25/ 


\section{Discrimination against girls based on gender typing}

The extent to which kindergarten culture initially appears to favour girls is largely due to the fact that it corresponds to wider cultural stereotypes. It seems it is easier for girls to accept requests for obedience in a kindergarten because of the cultural pattern that requires girls to be 'good, pretty and tidy'- a stereotype mainly accepted and sustained in the domestic and cultural tradition in Serbia (Trebješanin \& Jovanić, 2014).

Findings from neurological research (Landers, 2002; OECD, 2010) suggest that girls' preferences for role plays and more structured spaces with opportunities for sorting and classification have often been misused, reducing girls' choices to well-equipped play areas, such as the kitchen, family and hair salon - which maintains stereotypical female roles. From a sociocultural standpoint, the meanings of space and culture are co-constructed. Culture shapes the meaning of the space and vice versa - culture is built and maintained by its materialization through space. The existing space maintains the cultural patterns and supports the clichés of the female role - to be pretty, cook and raise children.

I'm always in the kitchen. And I like being there because I like tidying up and cooking lunch and playing alone. It is just like at home, mom cooks everything alone and I help her sometimes. /BZ18/

Opportunities to play roles close to children's experiences should not be excluded from kindergarten practice. It should be equally important to introduce additional opportunities for children to play other social roles and to support their imaginative play. As imagination is central to dramatic play, children should be encouraged to create new tools and means of play so they are not simply left with ready-made substitutes, keeping them in fixed patterns. Heavily structured spaces, such as play centres with ready-made materials and props, leave very little room for creativity, investigation and experimenting. Child play is habitually set within a stereotyped framework of repetitive activities and a limited repertoire of themes and roles which do not provide space for rich imaginative play:

[Explanation of a photo of their favourite place]

Because I like cooking and serving food. There are many dishes here and there's also food [points to plastic vegetables].

I make food and lunch and then set the table. Mateja eats or drives the food in the truck. Something like that. /SZO9/ 
I most like being in the play centre with the dolls.

Why? What do you like doing there?

My best friend Jana and I play family there. The two of us are sisters and the dolls are our daughters. We change their clothes and diapers, feed them, read stories to them and put them to bed. /SZ11/

Because you can do your hair, look at yourself in the mirror, style your hair, choose your hair-do. Sometimes I would like to be a real hairdresser. /BZ22/

The girls' statements clearly indicate the performances of gender typed play in the kitchen or hair salon play centres with the accompanying roles and established patterns. By contrast, the boys - free of the pressure to participate in a culturally accepted way in the 'kitchen' and adopt the associated female role in it - tend to more easily abandon the clichéd role models and develop imaginative play within the same space:

Look, this is a photo you took yesterday.

Yes, that's the kitchen.

Can you explain how you make all these tasty dishes you offered me? I cook them. I take that little stopper from the bottle and then I put it in the cup and then I cook the ice-cream. And then I put it on a little plate and you can eat it.

You really like making ice cream?

Yes. I really like eating ice cream!

And what else do you like making?

Poisonous salad.

And why do you call the salad poisonous?

Because it is deadly [laughing]

Eugh! If you make a poisonous salad for your guests you might poison them.

Nooo...they'll only get an upset stomach [laughing]. Mitza did.

Who's she?

Mitza the squirrel.

Who?

Hey, it's in the cartoon! /BM09/

Some girls would take on the role of 'little teacher'. As they are familiar with the teacher's activities, they would sometimes do chores for the teacher and adopt a patronising attitude to the other children, detaching themselves from their peers. 
How do you know you are important here in the kindergarten? ... and even the teachers are always telling me: "Nadja, go to the kitchen and bring the plates for a snack", or "Nadja, go and tell the cook how many of us there are for breakfast", or "Nadja, go to 'Pčlica' [the name of the other children's group] and tell them to come outdoors with us", and this is how I know they need me. /BZ1O/

Well, they are the big bosses in the kindergarten [pointing to the kindergarten manager who was passing by at that moment]so they have to watch that nobody makes a mistake.

And who might make a mistake?

Wednesday.

What do you mean when you say a teacher is on duty?

It means she stays until all the children go home. Even if there is only one child, she has to look after that child.

And me, all the time I have to, how can I say it..., I always have to do something.

Where?

Well in the kindergarten, here, there, everywhere./BZ16/

The status of being 'teacher's favourite' provides an opportunity for the child to be involved in adult work, reducing the distance between adult and child activities. However, as this work does not involve all the children, it could also lead to the 'favourite child' becoming detached from his or her peer community and by 'taking on the adult role' the child is denied the opportunity to participate in activities as a child. Because girls are awarded such status more frequently than boys, we could argue that becoming detached from peer community participation is a form of indirect discrimination against girls by teachers.

Certainly, not all girls fit into existing stereotypes within kindergarten activities. Some girls join in 'boys' activities' and are exposed to the same reprimands and punishments. The others might withdraw and chose individual activities like drawing or reading books.

[Explanation of a photo of their favourite place]

I like being here because I really like reading and all the books are here. There are also puzzles on the third shelf. I have loads of books which mom reads to me and I have papers to make things from. /BZ19/ 
Well, this is our bookshelf.

And why do you like being there?

Because there are books and then I take a book, read it and put it back in its place after...

...And who is this in the photo?

Anastasija.

What's she doing there?

Well, she didn't want to move when I took the photo /SZ15/.

Sometimes, teachers 'use' girls as a means of maintaining control over the boys' behaviour, thereby reinforcing the girls' stereotypical images of the boys:

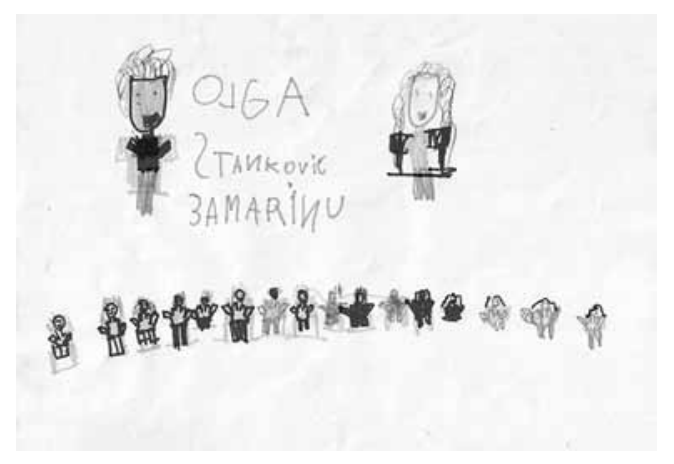

...I made a mistake here [pointing at her peers in the drawing]. First, I draw all my girlfriends, but I forgot that the boys have to sit next to the girls in the circle so I drew green boys.

Why do the girls have to sit next to the boys?

Well. Because the boys are restless. /SZ29/

This behaviour would not only reinforce girls' animosity toward boys but could possibly also reinforce the boys' stereotypical images of the girls:

How do you feel about the girls? Choose an emoticon.

[Luka chooses an emoticon with an angry face].

Why do you feel like that about the girls?

They are spoiled and real tell-tales. They are boring. /BM02/

Close friendships and sympathies

The dominant discourses about childhood and sexuality convey the general view in ECEC and in broader society that sexuality and gender issues are not relevant in early childhood (Robinson \& Diaz, 2006).

From birth, it is biologically 'instilled' in us that we should make social connections (National Scientific Council, 2004). Children are born as social beings - they seek out and become attached to others. The culture provides the models for how this attachment should evolve. It provides support and 
ways in which the attachment can develop. According to Olfman (2009) psychosexual development starts from the moment a new born feels sensual pleasure and bliss when being held and hugged by an adult. At a very early age the child learns to love and to be loved by establishing strong affective attachments with adults. These attachments give them a feeling of security and trust. Close affective relationships and empathy are the foundations of children's relational morality (Kagan in Gordon-Smith, 2009). The child has a prominent need for close and affective relationships with his/her peers. All the children's narratives in our research show how the children have a strong need to develop friendships with other children. The friendships are usually formed between children of the same gender, but we also found mixed gender friendships. In many of the children's narratives we found examples of 'sympathies' which were clearly differentiated from friendships:

[Drawing of the best day in kindergarten]

We play musical chairs, you see now I'm drawing the chairs, there are six of them. Here are Vuk and Novak and me and we are holding hands, our cheeks are a bit red because we've fallen in love. Dunja is next to me and she's holding my hand, now I'll draw you here beside Novak and you can play with us. /SMO4/

...And who helps you when you get scared?

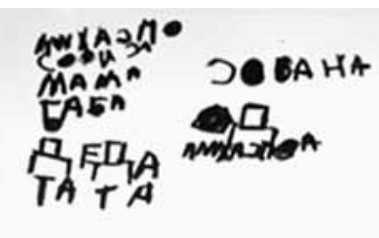

Luka, because he's in love with me and when Andrija chases me and I get scared he stands up to protect me. / BZ2O/

How do you feel in the kindergarten?

I feel happy. Mostly toward Stasha.

And why exactly toward Stasha?

Like you don't know, ha?

Well I don't know, really.

I like her, I thought you'd noticed.

No, I thought you were just friends.

Yes, but she also fancies me.

How do you know that?

She told me. /SMO4/ 


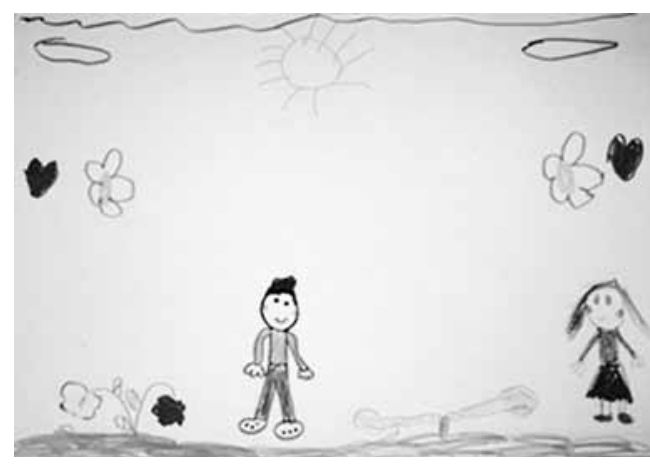

[Drawing of the best day in kindergarten]

We would play outdoors but only Alex and I. We could do anything, climb the slide, go on the swing, pick flowers. Then we could sing all the time and there would be no adults and they wouldn't know what we were doing. The weather would be nice and I could wear a skirt and he would be wearing his beautiful green trousers. I would be very happy because now the weather is bad we never go outdoors. /SZ15/

\section{Conclusions}

Our analyses of the children's narratives and statements strongly suggest that:

- Gender themes are very much present in children's narratives; however, in constructing and reconstructing gender themes children are mainly left to themselves and are exposed to social and cultural influences which could lead to gender typing;

- ECEC practice in Serbia is not clear on the issue of gender differences. In addition, kindergarten practice does not consistently conform to a particular gender discourse. On the one hand, it seems as if the practice is built around the discourse of biologically determined gender as it tolerates gender segregation. If this were the case, the practice would be more sensitive to the differences and specifics of gender groups, which is not the case. On the other hand, a firm belief in socially constructed gender differences is not built into the practice, because the practice is not sensitive to the gender segregation, gender typing and stereotyping it promotes.

Research with children helps us overcome the 'centrism of the researcher' that is prevalent in the type of research where the researcher deals only with themes closely linked to his or her own field of interest and/or the current direction of education policy and the theoretical field in which he or she works. Our research represents an example of how consultations with children could re-direct us away from an initial research focus and toward an important topic that has been unduly ignored both theoretically and in practice. That way our research has helped to raise awareness about the importance of gender issues within ECEC practice in Serbia. The data obtained 
indicate the need to critically reconsider existing practice and how it should be transformed. Further research with children focusing on the issue of gender would be a valuable contribution because, according to Mac Naughton (2000), "the most potent source of information about young children's gender knowings are the children themselves. Accessing these knowings is the key to meaningful gender equity work with children" (p.108). At the same time, it is important for research to focus on the teacher's perspective on gender and to support the process whereby teachers reconsider their own discourse on gender. Data gathered in research with children could contribute to raising awareness of how teachers' practice is shaped by such discourses. Teachers should question their own actions and relationships with children as well as kindergarten practices that reinforce and perpetuate gender stereotypes and challenge rigid, narrow and contradictory conceptions of what it means to be a girl or a boy, while trying to transform current practices.

Raising the issue of the gender structure of the ECEC profession is not only a question of increasing 'gender visibility', but it also represents an opportunity to re-think the main purpose of ECEC and preschool teachers' professionalism (Moss, 2000). This does not mean de-feminising kindergarten culture by accepting the 'masculinisation' of ECEC and importing the dominant 'male' principles of power by means of standardisation, effectiveness and external control (Mac Naughton, 2000, 2005; Robinson \& Diaz, 2006). On the contrary, what we need is transformative educational practice with teachers as reflexive practitioners, who are, according to Mac Naughton (2003)

attempting to change ideas, practices, stories and emotions that oppress people and produce inequality; promoting equality of opportunity and participation in education for all; opening up possibilities for all children; helping children to recognize and deal with what's fair and unfair in their world; creating a living democracy in the early childhood programme; building social action skills in children. (p. 188)

Finally, as many theorists of culture and early education argue (Buckingham \& Tingstad, 2007; Kapur, 2005; Kincheloe, 2011; Olfman, 2009), we live in a highly commercialised and sexualised society in which very young children are exposed to the commercialisation and sexualisation of childhood, not only through the general cultural milieu, but also through that aimed at children (children's movies, toys, picture books and comics, clothes, etc.). Children in contemporary society are "at risk for internalizing impoverished models of gender and human relationships" (Olfman, 2009, 
p.1), which leaves ECEC practice with the important task of becoming highly sensitive to these issues. For example, within ECEC, the usual response to sympathies among children is either to ignore them or attribute 'adult' meanings to them which do not reflect the meaning that closeness has for the children. A practice such as this could further reinforce the dominant socio-cultural tendencies instead of encouraging their deconstruction (Robinson, 2005).

As Vivienne Hogan (2013) points out, although it is difficult to provide a unique definition of feminist pedagogy, it is possible to identify key aspects, which are "a concern with relational teaching, exposing and challenging power relationships in the classroom and a general commitment to a democratic vision of education" (Hogan, 2013, p.49). We suppose these postulates could be used as the basis for a future pedagogical framework for the transformation of gender practice in early childhood education.

\section{References}

Alldred, P., \& Burman, E. (2005). Analysing children's accounts using discourse analysis. In S. Greene, \& D. Hogan (Eds.). Researching children's experience-approaches \& methods (pp.175-199). London: Sage Publication.

Anning, A., Cullen, J., \& Fleer, M. (2004). Early Childhood Education, Society \& Culture. London: Sage Publication.

Aydt, H., \& Corsaro, W.A. (2003). Differences in children's construction of gender across culture: An interpretive approach. American Behavioral Scientist, 46(10), 1306-1325.

Berkowitz, S. (1997). Analyzing qualitative data. In J. Frechtling \& L. Sharp (Ed.). User friendly handbook for mixed method evaluations. Arlington, VA: Division of Research, Evaluation and Communication, National Science Foundation. Retrieved February 7, 2010, from http://www.nsf.gov/pubs/1997/nsf97153/start.htm.

Blaise, M. (2005). Playing it straight - Uncovering gender discourses in the early childhood clasroom. New York: Routledge.

Browne, N. (2004). Gender equity in the early years. London: Open University Press. Buckingham, D., \& Tingstad, V. (2007). Consuming children commercialisation \& the changing construction of childhood. Barn, (2), 49-71.

Burman, E. (2005). Childhood, neo-liberalism and the feminization of education. Gender and Education. 17(4), 251-267.

Clark, A., \& Moss, P. (2001). Listening to young children. The Mosaic Approach. London: National Children's Bureau.

Clark, A. (2005). Ways of seeing: Using the mosaic approach to listen to young children's perspectives. In A. Clark, A. T. Kjørholt, \& P. Moss (Eds.). Beyond listening. Children's perspectives on early childhood services (pp. 29-49). Bristol: Policy Press. Clark, A., A. T. Kjørholt, \& Moss, P. (Eds.). (2005). Beyond Listening. Children's perspectives on early childhood services. Bristol: Policy Press. 
Christensen, P., \& James A. (2008). Research with children: Perspectives and practice. London: Falmer Press.

Cunningham, J., Walsh,G., Dunn, J., Mitchell, D., \& McAlister, M. (2004). Giving children a voice: Accessing the views \& interests of three-four year old children in play group. Belfast: Stranmillis University College.

Dahlberg, G., Moss, P., \& Pence, A. (2007). Beyond quality in early childhood education \& care. (2 $2^{\text {nd }}$ Edition). New York: Routledge.

Dalli, C.E., \& Stephenson, A. (2010). Involving children in research in early childhood education settings: Opening up the issues. In J. Loveridge (Ed.). Involving children \& young people in research in educational settings (pp. 11-47). Wellington: New Zealand Ministry of Education.

Davies, S., \& Thurston, M. (2006). Consulting with children under five-A literature review. Chester: University of Chester.

Denzin, N., \& Lincon, I.S. (2011). Introduction: The discipline \& practice of qualitative research. In N. Denzin, \& I. S. Lincon (Eds.). The SAGE handbook of qualitative research (pp.1-31). (4th ed). London: Sage Publishing.

Edley, N. (2001). Discourse as data a guide for analysis. London: Sage: Publications Ltd. Einarsdottir, J., (2005). We can decide what to play. Early Education \& Development, 16(4), 471-488.

Gadamer, H-G. (2011). Istina i metod-Osnovi filozofske hermeneutike. Beograd: Fedon. Gordon-Smith, P. (2009). The morality of young children in their early years setting. Childhoods Today, Special Issue.

Grewal, I., \& Kaplan, C. (2006). An introduction to women's studies: Gender in a transnational world. New York: McGraw Hill.

Harcourt, D. (2008). Constructing ideas \& theories about quality: The accounts of young children in two early childhood classrooms in Singapore. Unpublished $\mathrm{PhD}$ thesis. Brisbane, Australia: Queensland University of Technology.

Hatch, J.A. (2002). Doing qualitative research in education settings. Albany: State University of New York Press.

Hogan, V. (2012). Locating my teaching of gender in early childhood educationteacher education within the wider discourse of feminist pedagogy and poststructuralist theory. Paper presented at the Joint AARE APERA International Conference, Sydney 2012.

Hogan, V. (2013). Revisiting the 'Teachers' Gaze': Have we changed how We 'See' gender in early childhood education? He Kupu, 3(3), 44-53.

Landers, C. (2002). Gender: What science tells us. Background reading for gender socialisation in early childhood development. UNICEF, ECD Resource Pack.

Jarić, I. (2006). Rekonfiguracija hegemonih modela (muških i ženskih) rodnih uloga $\mathrm{u}$ procesu transformacije srpskog društva [Reconfiguration of Hegemonic Models of (male and female) gender roles in the transformation of serbian society]. Filozofija i društvo, 30(2), 175-191.

Kapur, J. (2005). Coining for capital - Movies, marketing, \& the transformation of childhood. New Brunswick: Rutgers University Press.

Kellett, M. (2005). Children as active researchers: A new research paradigm for the $21^{\text {st }}$ century? London: Centre for Childhood, Development and Learning, The Open University. 
Kincheloe, J.L. (2011). The complex politics of McDonald's \& the new childhood: Colonizing kidworld. International Critical Childhood Policy Studies, 4(1), 1-46.

Krnjaja, Ž., \& Pavlović Breneselović, D. (2013). Gde stanuje kvalitet-politika građenja kvaliteta u predškolskom vaspitanju [Where is the quality - Quality development policy in ECEC]. Beograd: Institut za pedagogiju i andragogiju.

James, A., \& Prout, A. (2005). Re-presenting childhood: Time \& transition in the study of childhood. In A. James, \& A. Prout (Ed.). Constructing \& reconstructing childhood (pp. 227-247). (2 $2^{\text {nd }}$ Edition). London: Taylor \& Francis e-Library.

Mac Naughton, G. (2000). Rethinking gender in early childhood education. St. Leonards NSW: Allen \& Unwin.

Mac Naughton, G. (2003). Shaping early childhood: Learners, curriculum \& contexts. Maidenhead, UK: Open University Press.

Mac Naughton, G. (2005). Doing Foucault in early childhood studies. Applying poststructural ideas. London \& New York: Rutledge.

Mac Naughton, G., Smith, K., \& Lawrence, H. (2008). Hearing young children's voices. Melbourne: Children's Services Branch, ACT Department of Education, Youth \& Family Services.

Mahony, K., \&Hayes, N. (2006). In search of quality: Multiple perspectives, final report. Dublin: The Centre for Early Childhood Development \& Education.

Maxwell, J., \& Miller B.A. (2008). Categorizing and connecting strategies in qualitative data analysis. In S. N. Hesse-Biber, \& P. Leavy (Eds). Handbook of emergent methods (pp. 461-479). London \& New York: The Guilford Press.

Moss, P. (2000). Workforce issues in early childhood education \& care. Consultative Meeting on International Developments in Early Childhood Education \& Care, The Institute for Child \& Family Policy Columbia University, New York, May 11-12, 2000. National Scientific Council on the Developing Child (2004). Young children develop in an environment of relationships. Working paper No 1. Centre on the Developing Child, Harvard University.

OECD (2010). Razumeti mozak: Rođenj enauke o učenju [Understanding the brain]. Beograd: OECD/Ministarstvo prosvete RS.

Olfman, S., (2009). The sexualization of childhood: Growing older younger/growing younger older. In S. Olfman (Ed.). The sexualization of childhood (pp. 1-7). Westport, CT: Praeger Publishers.

O'Kane, C. (2008). The development of participatory techniques: Facilitating children's views about decisions which affect them. In P. Christensen, \& A. James (Eds.). Research with children: Perspectives and practices (pp.136-160). London \& New York: Falmer Press.

Peeters, J. (2007). Including men in early childhood education: Insights from the European experience. NZ Research in Early Childhood Education, 10,15-24.

Peters, S., \& Kelly, J. (2011). Exploring children's perspectives: Multiple ways of seeing \& knowing the child. Waikato Journal of Education, 16(3), 19-30.

Pramling Samuelsson, I. (2004). How do children tell us about their childhoods? ECRP, 6(1). Retrived from http://www.ecrp.uiuc.edu/v6n1/pramling.html

Qvortrup, J. (Ed.) (2005). Studies in modern childhood-society, agency, culture. New York: Palgrave Macmillan.

Robinson, K.H. (2005). Childhood \& sexuality: Adult constructions \& silenced chil- 
dren. In J. Mason, \& T. Fattore (Eds.). Children taken seriously in theory, policy \& practice (pp.66-79). London \& Philadelphia: Jessica Kingsley Publishers.

Robinson, K.H., \& Diaz, J. C. (2006). Diversity and difference in early childhood education: Issues for theory and practice. Maidenhead: Open University Press.

Rogoff, B. (2003). The cultural nature of human development. Oxford: Oxford University Press.

Rolfe, H. (2006). Where are the men? Gender segregation in the childcare and early years sector. National Institute Economic Review, (195), 103-117.

Sandelowski, M., \& Barroso, J. (2007). Handbook for synthesizing qualitative research. New York: Springer.

Shonkoff, J.P., \& Philips, D.A. (Eds.). (2000). From neurons to neighborhoods: The science of early childhood development. Washington DC: National Academy Press.

Sommer, D., Pramling Samuelsson, I., \& Hundeide, K. (2010). Child perspective and children's perspectives in theory and practice. London: Springer.

Trebješanin, Ž., \& Jovanić, G. (2014). Promene u shvatanju deteta u srpskoj kulturi $\mathrm{u}$ poslednjih dvadeset pet godina [Changing conceptions of the child in serbian culture over the past twenty-five years]. Primenjena psihologija, 7(4), 549-563.

Yelland, N., \& Grieshaber, N. (1998). Blurring the edges. In N. Yelland (Ed.). Gender in early childhood (pp.1-15). London: Routledge.

Wardle, F. (2007). The challenge of boys in our early childhood programs. Early Childhood News. 16(1), 16-21.

\section{Authors:}

Dragana Pavlović Breneselović, professor

University of Belgrade

Faculty of Philosophy

Department of Education

Cika Ljubina 18-20

Belgrade

Serbia

Email: dbrenese@f.bg.ac.rs

Živka Krnjaja, associate professor

University of Belgrade

Faculty of Philosophy

Department of Education

Cika Ljubina 18-20

Belgrade

Serbia

Email: zivka.krnjaja@f.bg.ac.rs 